\title{
Manajemen Program Kelas Unggulan untuk Meningkatkan Citra Madrasah Tsanawiyah 1 Kabupaten Madiun
}

\author{
Lukman Hakim \\ IAIN Ponorogo, Indonesia \\ Email: Lukmanachim19@gmail.com \\ Yoga Dwi Utami \\ IAIN Ponorogo, Indonesia \\ Email:yogadwiutamin@gmail.com
}

DOI: https://doi.org/10.21154/ sajiem.v2i1.37

\begin{abstract}
The world of education enters this global era with all its advantages and challenges. Under conditions of harsh competition like this, the role of a strong image will be increasingly important for service providers in winning competition. It is in this context that Islamic education institutions carry out strategies to improve the image of madrasah. Madrasah Tsanawiyah 1 Kabupaten Madiun has held the superior class program to improve the madrasah's image. Based on the process of collecting and analyzing data, researchers produce: (1) Management of a superior class program to improve the image of madrasah in MTsN 1 Madiun Regency, that is: Planning (objectives, programs, budgets). Organizing (organizational structure, educators, students, materials, infrastructure, costs). Implementation (Before teaching, Teaching and After teaching). Evaluation (Formative, Summative, Test and Nontest). (2) obstacles: (a) Planning: Limited budget, Depends on parents' contributions. (b) Organizing: Special curriculum has not yet been realized, Allocation of learning hours, The lack of teaching staff. (c) Implementation: The existence of ups and downs, clash with other importances, facilities that are not quickly met, Limited guidance time, Clash schedule, Test season, Rainy season, Students are not proportional to the number of teachers and teachers have not maximally applied IT based learning. (d) Evaluation: There are changes in report cards from manual to ARD, Not all teachers understand about IT and the limited facilities for evaluation. (3) The Implications of Management of a Superior Class Programs include: Having good quality, many achievements, excellence in science and technology and Faith and piety, good, advanced and favorite schools and Having the facilities to develop students' abilities, talents and interests.
\end{abstract}

Keywords: management, superior class program, image of madrasah 


\section{Pendahuluan}

Pada umumnya, madrasah sebagai lembaga pendidikan Islam kalah dalam persaingan global. Permasalahan utama dalam lembaga pendidikan Islam adalah berkenaandengan pengelolaan atau manajemennya. Haltersebut mempengaruhi rendahnya kualitaslembaga pendidikan Islam di Indonesia. ${ }^{1}$ Tantangan yang paling nyata terhadapkeberadaan lembagalembaga pendidikan Islam adalah: (1) Pendidikan diselenggarakan dengan manajemen seadanya, (2) Kurangadanya publikasi lembaga pendidikan Islam kemasyarakat luas, (3) Banyaknya warga Muslimyang lebih memilih sekolah lain karena faktormutu dan kualitas sekolah tersebut, (4) Banyakmasyarakat yang tidak mengenal madrasahsecara utuh sebagai pendidikan modern. ${ }^{2}$ Jadi, selain harus merespon perubahan era globalisasi, madrasah harus mampu mengenali dan mengidentifikasi masalah yang di hadapi serta meningkatkan mutu dan kualitas pendidikannya.

Madrasah sebagai lembaga pendidikan yang berada dalam kisaran era globalisasi harus selalu melakukan inovasi tanpa henti, jika ingin tetap memperoleh simpati konsumen. Jika tidak maka madrasah akan ditinggalkan konsumen, yaitu beralih ke lembaga pendidikan lain yang terus berinovasi. Jika inovasi tidak dilakukan, berarti madrasah tersebut tidak serius meningkatkan kualitasnya. ${ }^{3}$ Proses pembelajaran pada setiap satuan pendidikan dasar dan menengah harus interaktif, inspiratif, menyenangkan, menantang dan memotivasi peserta didik untuk berpartsipasi aktif, serta memberikan ruang yang cukup bagi prakarsa, kreatifitas dan kemandirian sesuai dengan bakat, minat, dan perkembangan fisik, serta psikologis peserta didik. ${ }^{4}$ Maka, madrasah sebagai penyedia jasa pendidikan harus melakukan inovasi pendidikan yang pada pelaksanaanya tetap memperhatikan minat dan bakat peserta didik.

Dibandingkan negara tetangga se-Asia Tenggara, keterampilan atau skill dari SDM Indonesia menempati peringkat keempat dibawah singapura, malaysia, dan Brunei Darussalam. Hal tersebut berdasarkan salah satu pilar penilaian dalam indeks Daya Saing Global (GCI) yang dirilis oleh World Economy Forum (WEF) pada 2018. ${ }^{5}$ Berdasarkan data tersebut, maka madrasah harus menciptakan kondisi dimana ia tidak hanya berperan dalam mentransfer ilmu, tetapi juga mampu mengembangkan potensi dan keterampilan peserta didik sesuai dengan minat dan bakatnya.

Dalam era informasi sekarang ini, dimana konsumen dijejali dengan berbagai infomasi, khususnya tentang produk dan jasa, dalam jumlah yang banyak melalui berbagai media, seperti media cetak dan elektronik, maka upaya untuk membangun citra menjadi semakin sulit. Dalam kondisi persaingan yang keras seperti ini, maka peranan citra yang kuat akan semakin penting bagi perusahaan jasa dalam memenangkan persaingan. ${ }^{6}$ Keunggulankeunggulan yang menjadikan suatu sekolah berbeda dengan sekolah lain menjadi fondasi kuat untuk membangun citra. Jika keunggulan-keunggulan tersebut dijaga dan dikembangkan secara dinamis, maka citra sekolah yang positif akan semakin melekat pada konsumen. Citra perlu dibangun untuk memudahkan konsumen memilih produk atau memanfaatkan jasa yang sesuai dengan keinginan dan kemampuannya. ${ }^{7}$ Citra yang baik atau positif dari sebuah lembaga akan memberikan dampak yang menguntungkan untuk lembaga. Sebaliknya, apabila citra yang terbangun negatif, maka akan merugikan lembaga tersebut. Citra yang baik atau positif dari suatu lembaga atau organisasi merupakan aset, karena citra mempunyai dampak

\footnotetext{
${ }^{1}$ Suryadi, Manajemen Mutu Berbasis Sekolah (Bandung: PT Sarana Panca Karya Nusa, 2009), 38.

${ }^{2}$ Ibid., 44.

3 Jamal Ma'mur Asmani, Manajemen Efektif Marketing Sekolah (Yogyakarta: Diva Press, 2015), 128.

${ }^{4}$ Rusman, Model-model Pembelajaran (Jakarta: PT Rajagrafindo Persada, 2013), 4.

5 Rizky Alika, "Nadiem: Anak Indonesia Krisis Percaya Diri, Butuh Manajemen Talenta", 23 Desember 2019, https://katadata.co.id/berita/2019/12/23/nadiem-anak-indonesia-krisis-percaya-diributuh-manajemen-talenta, diakses tanggal 26 Januari 2020

${ }^{6}$ Muhammad Adam, Manajemen Pemasaran Jasa (Bandung: Alfabeta, 2015), 54.

${ }^{7}$ Asmani, Manajemen Efektif Marketing Sekolah, 208-209.
} 
pada persepsi publik atau masyarakat. ${ }^{8}$ Maka dari itu, jika madrasah ingin mempertahankan eksistentensinya, maka madrasah harus membangun citra positif madrasah, sehingga persepsi masyarakat terhadap madrasah baik, dan madrasah diminati oleh peserta didik dan masyarakat.

MTsN 1 Kabupaten Madiun merupakan satu-satunya Madrasah Tsanawiyah yang berstatus Negeri di Kecamatan Dolopo, ${ }^{9}$ dan merupakan salah satu Madrasah yang cukup diminati di Kecamatan Dolopo. Dibuktikan dengan banyaknya rombel yakni sebanyak 27 rombel dan 758 siswa, dengan jumlah kelas VII sebanyak 277 siswa, kelas VIII sebanyak 252 siswa dan kelas IX sebanyak 229 siswa. Namun, berbagai hambatan dihadapi oleh madrasah ini. Terdapat beberapa label negatif yang disematkan pada madrasah ini, diantaranya: label sekolah pinggiran, madrasah dengan manajemen kurang bagus, madrasah dengan siswa tidak berprestasi, serta madrasah yang hanya mementingkan pelajaran agama. ${ }^{10}$ Hal ini dapat mempengaruhi persepsi masyarakat tentang MTsN 1 Kabupaten Madiun, sehingga menimbulkan citra yang negatif terhadap madrasah.

Dari penjajagan awal di MTsN 1 Kabupaten Madiun, ditemukan beberapa upaya untuk meningkatkan citra positif madrasah, salah satunya adalah dengan menyelenggarakan program kelas unggulan. Program kelas unggulan ini dilaksanakan untuk memenuhi kebutuhan peserta didik yang berbeda, serta potensi peserta didik yang berbeda dari umumnya. Selain itu, dengan program kelas unggulan citra madrasah dapat terangkat. Sebab, MTsN I Madiun dapat menjadi madrasah yang unggul dan baik dalam prestasi akademik maupun non akademik. Program kelas unggulan yang dilaksanakan di MTsN 1 Kabupaten Madiun diantaranya yaitu kelas prestasi, kelas tahfidz, kelas multimedia (IT) serta kelas olah raga dan seni. Untuk mengikuti program kelas unggulan tersebut, seorang siswa harus memenuhi beberapa syarat khusus. Syarat khusus kelas prestasi yaitu mengikuti uji kendali mutu, sedangkan syarat khusus kelas tahfidz yaitu mengikuti tes membaca dan hafalan alQur'an, dan syarat khusus kelas multimedia yaitu memiliki laptop dan mengkuti tes peminatan, sedangkan syarat khusus kelas olah raga dan seni yaitu melampirkan fotocopy sertifikat kejuaraan olah raga dan seni serta mengikut tes lapangan (praktek). Sedangkan citra yang ingin dibangun melalui program kelas unggulan ini adalah, siswa yang mengikuti program kelas prestasi dapat berprestasi dalam bidang akademik, hafal juz 30, menguasai 2 bahasa yaitu bahasa inggris dan bahasa arab. Siswa yang mengikuti kelas tahfidz dapat menghafalkan al-qur'an sebanyak 7 juz, mahir dalam dakwah. Siswa yang mengikuti kelas multimedia/IT dapat mengoperasikan aplikasi perkantoran, desain grafis, video editing dan hafal juz 30. Sedangkan siswa yang mengikuti program kelas Olahraga dan seni dapat memiliki kemampuan di bidang atletik, permainan, aksioma dan seni, serta hafal juz 30." Hal ini menunjukkan bahwa MTsN 1 Kabupaten Madiun menyelenggarakan program kelas unggulan untuk meningkatkan citra madrasah.

Melihat fenomena diatas, maka diharapkan strategi progam kelas unggulan yang diterapkan MTsN 1 Kabupaten Madiun dapat meningkatkan citra positif madrasah dan dapat mengatasi permasalahan madrasah sebagai penyedia jasa. Berdasarkanalurpemikirandantemuandiatas maka artikel ini berjudul "Manajemen Program Kelas Unggulan untuk Meningkatkan Citra Madrasah (Studi Kasus di MTsN 1 Kabupaten Madiun)".

\footnotetext{
${ }^{8}$ Elvinaro Adrianto, Public Relation Praktis (Bandung: Widya Padjajaran, 2009), 20.

${ }^{9}$ https://referensi.data.kemendikbud.go.id/index11.php?level=3\&kode=050803\&id=10, diakses hari Kamis, o9 Januari 2020 jam: 06.05.

${ }^{10}$ Agus Salim, Wawancara, Madiun, o9 September 2019.

${ }^{11}$ Ibid.
} 


\section{Penerapan Fungsi Manajemen dalam Program Kelas Unggulan untuk Meningkatkan Citra Madrasah Di MTsN 1 Kabupaten Madiun}

Keberhasilan suatu program pembelajaran terletak pada bagaimana fungsi manajemen program itu dijalankan. Baik dari perencanaan, pengorganisasian, pelaksanaan dan evaluasi. Keempat fungsi tersebut harus berjalan dengan efektif dan efisien agar tujuan dari program pebelajaran itu dapat tercapai. Begitu juga dengan apa yang terjadi di MTsN 1 Kabupaten Madiun dalam melaksanakan Program Kelas Unggulan untuk meningkatkan citra madrasah. Berikut paparan tentang penerapan fungsi manajemen dalam program kelas unggulan di MTsN 1 Kabupaten Madiun untuk meningkatkan citra madrasah.

1. Perencanaan

Program kelas unggulan di MTsN 1 Kabupaten Madiun terdiri dari 4 pilihan program, yaitu: kelas excellent, kelas tahfidz, kelas multimedia, dan kelas olahraga dan seni. Program kelas unggulan tersebut diselenggarakan berdasarkan potensi siswa yang berbeda-beda, selain itu juga untuk memenuhi tuntutan pasar yang dalam hal ini adalah masyarakat, sehingga banyak masyarakat yang mendaftarkan anaknya di madrasah ini. Hal ini sebagaimana yang disebutkan oleh Ibrahim Bafadal dalam teori yang menyebutkan bahwa Perencanaan dapat didefinisikan sebagai keseluruhan proses pemikiran dan penentuan semua tugas dan kegiatan yang akan dilakukan pada masa yang akan datang dalam rangka mencapai tujuan yang telah dirumuskan. ${ }^{12}$

Selain menyelenggarakan beberapa pilihan program kelas unggulan, MTsN 1 Kabupaten Madiun juga menentukan tujuan dari masing-masing program kelas unggulan. Tujuan dari program kelas excellent atau prestasi adalah 1) Terwujudnya Prestasi Akademik hasil Bimbingan/ Intensif Belajar Ujian Nasional dengan hasil Ujian Nasional terbaik tingkat kabupaten. 2) Terwujudnya Prestasi di Kompetisi Sains Madrasah (KSM) tingkat Kabupaten dan Tingkat Propinsi. 3) Siswa mampu mengadakan Penelitian dan Membuat Laporan Hasil penelitian (baik bidang IPA maupun IPS), sehingga Terwujud Prestasi di Lomba Penulisan Karya Tulis Ilmiah. 4) Terwujudnya pembelajaran dan bimbingan secara efektif, kreatif dan inovatif sehingga setiap siswa dapat berkembang secara optimal, sesuai dengan potensi yang dimiliki. 5) Menumbuhkan sikap kompetitif untuk mendapatkan hasil terbaik. 6) Siswa memperoleh pengalaman belajar Melalui Pembelajaran Kontekstual (Kunjungan di Industri Kreatif, Museum, tempat sejarah, dan tempat lainnya) untuk Meningkatkan Kompetensi dan membentuk karakter siswa. Tujuan dari kelas olahraga adalah 1) Memberikan bimbingan khususnya di bidang olah raga, kepada anak-anak yang berbakat di bidang olah raga. 2) Menciptakan siswa yang berprestasi di bidang olah raga, minimal juara di tingkat kabupaten. 3) Memberikan pelatihan yang terstruktur di bidang olahraga sesuai dengan keahliannya sesuai bakatnya. Tujuan dari kelas tahfidz adalah untuk mencetak generasi qur'ani, agar anak mampu membaca al-Qur'an dengan baik dan benar, dapat membaca al-Qur'an dengan makhroj dan tajwid yang benar serta dapat menghafal al-Qur'an. Dan tujuan kelas multimedia adalah membekali anak dengan keterampilan IT, agar anak mahir mengoperasikan komputer, anak mahir aplikasi dasar perkantoran seperti Microsoftword, Microsoft excell, Microsoftpowerpoint, serta mahir designgrafis dan videoediting.

Tujuan-tujuan tersebut sebagaimana yang disebutkan oleh Kompri dengan teori yang menyebutkan bahwa tujuan pengembangan kelas unggulan adalah 1) Mempersiapkan siswa yang memiliki kecerdasan, keimanan dan ketakwaan kepada Tuhanyang Maha Esa, memiliki budi pekerti yang luhur, memiliki pengetahuandan keterampilan serta sehat jasmani dan rohani.2) Memberikan kesempatan kepada siswa dengan kecerdasan di atasrata-rata normal untuk mendapatkan pengetahuan dan keterampilan yangsesuai dengan potensinya. 3) Memberikan kesempatan kepada siswa agar lebih cepat dalam

\footnotetext{
${ }^{12}$ Ibrahim Bafadal, Manajemen Peningkatan Mutu Sekolah Dasar (Jakarta: Bumi Aksara, 2012), 42.
} 
mentransfer ilmupengetahuan dan teknologi yang diperlukan sesuai dengan perkembanganpembangunan zaman. 4) Memberikan penghargaan kepada siswa yang berprestasi baik. Dan 5) Mempersiapkan lulusan kelas unggulan menjadi siswa unggulandalambidang pengetahuan dan teknologi sesuai denganperkembangan mentalsiswa. ${ }^{13}$

Selain menentukan tujuan dari masing-masing program, dalam perencanaan program kelas unggulan di MTsN 1 Kabupaten Madiun juga dirumuskan terkait anggaran, target masing-masing program serta kegiatan-kegiatan apa saja yang dilakukan oleh masing-masing program untuk mencapai tujuan.

Hal ini sebagaimana yang disebutkan oleh Nana Syaodih Sukmadinata dengan teori yang menyebutkan bahwa Dalamperencanaan terdapat tiga kegiatan, yaitu: 1) perumusan tujuan yang ingin dicapai;2) pemilihan program yang tepat untuk mencapai tujuan; dan 3) mengidentifikasi dan mengerahkansumber yang jumlahnya selalu terbatas.Dalam perencanaan ditentukan tujuanatau sasaran organisasi yang hendak dicapai dan menetapkan jalan dan sumber yangdiperlukan untuk mencapai tujuan organisasi seefisien dan seefektif mungkin. ${ }^{14}$

Dalam perencanaan program kelas unggulan ada beberapa pihak yang terlibat diantaranya yaitu Kepala Sekolah, Wakil Kepala Sekolah terutama Kurikulum, Koordinator masing-masing program kelas unggulan, serta perwakilan dari guru. Hal ini sebagaimana yang disebutkan Ibrahim Bafadal dengan teori yang menyebutkan bahwa perencanaan yang baik adalah dibuat oleh orang-orang yang memahami seluk beluk organisasi, dibuat oleh orang-orang yang memahami perencanaan, disertai dengan rincian yang teliti, tidak terlepas dari pemikiran pelaksanaan, terdapat tempat pengambilan resiko, sederhana, luwes dan praktis, didasarkan pada keadaan nyata masa kini dan masa depan, dibuat bersama, direkomendasikan oleh orang dengan jabatan tertinggi. ${ }^{15}$

Dalam fungsi perencanaan terdapat beberapa model perencanaan yaitu Model Perencanaan Komprehensif, Model Target Setting, Model Costing dan Model PPBS. ${ }^{16}$ Jika dlihat dari proses perencanaan yang dilakukan oleh MTsN 1 Kabupaten Madiun maka dapat dipahami bahwa Model perencanaan yang dilaksanakan adalah mengacu pada model PPBS (Planning, Programming, Budgeting System), karena dalam perencanaan tersebut ditentukan tujuan, program kegiatan juga anggaran atau biayanya. Hal ini sebagaimana yang disebutkan oleh Didin Kurniadin dan Imam Machali dengan teori yang menyebutkan bahwa Model PPBS (Planning, Programming, Budgeting System). PPBS memandang bahwa perencanaan, penyusunan program, dan penganggaran adalah sebagai suatu sistem yang tak terpisahkan antara satu sama lainnya. Kast Rosenzweig mengemukakan bahwa PPBS merupakan suatu pendekatan sistematik yang berusaha untuk menetapkan tujuan, mengembangkan program-program yang akan dicapai, menemukan besarnya biaya dan alternatifnya, dan menggunakan proses penganggaran yang mencakup kegiatan program jangka panjang. ${ }^{17}$

2. Pengorganisasian

Untuk kelancaran dan kesuksesan program kelas unggulan di MTsN 1 Kabupaten Madiun, diperlukan sumber daya-sumber daya yang berkompeten. Di MTsN 1 Kabupaten Madiun ditentukan juga sumber daya-sumber daya tersebut. Yaitu struktur organisasi, pendidik,

${ }^{13}$ Kompri, Manajemen Pendidikan (Komponen-Komponen Elementer Sekolah) (Yogyakarta: ArRuzz Media, 2015), 97-98.

${ }^{14}$ Nana Syaodih Sukmadinata, et.al., Pengendalian Mutu Pendidikan Sekolah Menengah (Bandung: Refika Aditama, 2006), 37.

${ }^{15}$ Bafadal, Manajemen Peningkatan Mutu Sekolah Dasar, 43.

${ }^{16}$ Didin Kurniadin dan Imam Machali, Manajemen Pendidikan: Konsep dan Prinsip Pengelolaan Pendidikan (Yogyakarta: Ar-Ruzz Media, 2012), 177-178.

${ }^{17}$ Ibid. 
peserta didik, materi, sarana prasarana dan biaya. Struktur organisasi program kelas unggulan di MTsN 1 Kabupaten Madiun yaitu: Penanggung Jawab: Kepala Madrasah, Ketua Program: Asrofi Hamami Taqqiyudin, S.Ag, MA (Wakamad Kuriklum), Koordinator Kelas Exellent: Ketua: Syaiful Muchson, S.Pd, Sekretaris : Imroatul Hajidah, S.Psi, Bendahara: Sunarti, S.Pd, Koordinator kelas Olah Raga: Ketua: Purwanto, S.Pd, Sekretaris : Afiv Febri Affandi, S.Pd, Bendahara: Farid Tri Nur Erwanto, Koordinator kelas Media Ketua: Evi Mutawasit, S.Kom, Sekretaris: SY. Rochmad Abdul Aziz S., S.Hum, Bendahara: Anugraheni, S.Pd. Koordinator Kelas Tahfidz Ketua: Mulyono, S.Ag, Sekretaris: Nurul Wahidah, S.Ag, Bendahara: Dra. Siti Syamsiatun. Hal ini sebagaimana yang sebutkan oleh Nanang Fattah dalam teori bahwa pengorganisasian sebagai proses pembagian kerja kedalam tugas-tugas yang lebih kecil, membebankan tugas-tugas tersebut kepada orang, sesuai dengan kemampuannya, dan mengalokasikan sumberdaya, sertamengkoordinasikannya dalam rangka efektivitas pencapaian tujuan organisasi. ${ }^{18}$

Sedangkan untuk pendidik program kelas unggulan di MTsN 1 Kabupaten Madiun adalah mereka yang memang benar-benar berkompeten di bidangnya. Di MTsN 1 Kabupaten Madiun ini pendidik program kelas unggulan diambilkan dari Madrasah dan dari luar Madrasah yang memang benr-benar memiliki keahlian dan kompetensi dibidangnya. Hal ini sebagaimana teori yang disebutkan oleh Kompri bahwa Guru kelas unggulan adalah guru kelas dengan ijazah minimal strata 1, yang mengampu bidang studi khusus atau mata pelajaran tertentu. Dengan demikian diharapkan guru kelas yang mengajar di kelas unggulan mempunyai kualifikasi dan dedikasi yang tinggi untuk mendukung pembelajaran kelas unggulan tersebut. ${ }^{19}$

Untuk pengorganisasian peserta didik program kelas unggulan, MTsN 1 Kabupaten Madiun melakukan seleksi saat penerimaan peserta didik baru. Adapun materi yang diujikan adalah untuk kelas excellent materi IPA dan Matematika, untuk kelas tahfidz materi baca tulis al-qur'an, untuk kelas multimedia materi tesnya adalah mengoperasikan komputer dasar dan untuk kelas olahraga dan seni materi tesnya adalah sesuai dengan keahlian yang dimiliki oleh peserta didik. Jadi anak yang mengikuti program kelas unggulan adalah mereka yang lolos seleksi dan berbakat dibidangya. Hal ini sebagaimana yang disebutkan oleh Kompri dalam teorinya bahwa Siswa kelas unggulan adalah siswa yang memiliki suatu keunggulan atau menonjol dalam hal: kesiagaan mental, kemampuan pengamatan/observasi, keinginan untuk belajar, daya konsentrasi, daya nalar, kemampuan membaca, ungkapan verbal, kemampuan menulis, kemampuan mengajukan pertanyaan yang baik, menunjukkan minat yang luas, memiliki ambisi yang kuat untuk mencapai prestasi, yang baik, mandiri dalam memberikan pertimbangan, dapat memberi jawaban tepat dan langsung ke sasaran, mempunyai rasa humor yang tinggi, dan melibatkan diri sepenuhnya serta ulet menghadapi tugas yang diminati. ${ }^{20}$

Terkait dengan Materi Program kelas unggulan, MTsN 1 Kabupaten Madiun menyusun materi-materi tambahan yang sesuai dengan masing-masing program kelas unggulan. Untuk materi kelas unggulan diantaranya yaitu mata pelajaran Ujian Nasional, Matematika, Bahasa Indonesia, IPA dan Bahasa Inggris. Juga ada tambahan untuk olimpiade IPA, IPS dan matematika. Untuk materi kelas olahraga dan seni yaitu Kelas 7 materinya teknik dasar, kelas 8 dan 9 pendalaman teknik dasar. Selain itu juga ada program wajib yang harus di ikuti, untuk siswi wajib ikut bola voley, untuk laki-laki wajib ikut futsal atau sepak bola kemudian juga diwajibkan mengikuti salah satu cabang pilihan olah raga, minimal satu cabang, yaitu tenis meja, bulu tangkis, dan catur. Materi kelas multimedia yaitu untuk kelas 7 materinya tentang basic aplikasi perkantoran, microsoft word dan Microsoft excel, kelas 8 yaitu multimedia dan design grafis, baik corel draw atau

\footnotetext{
${ }^{18}$ Nanang Fattah, Landasan Manajemen Pendidikan (Bandung: Remaja Rosdakarya, 2009),71.

${ }^{19}$ Kompri, Manajemen Pendidikan (Komponen-Komponen Elementer Sekolah), 100.

${ }^{20}$ Ibid., 99 .
} 
photoshop, untuk yang multimedianya itu editingvideo dan materi kelas 9 yaitu design grafis lanjutan dan koding sederhana. Sedangkan untuk kelas tahfidz materi wajib adalah tahfidz juz 30 dan untuk selebihnya tidak ada target khusus, tergantung dengan kemampuan siswa. Hal ini sebagaimana yang disebutkan oleh Suhartono dan Ngadirun dalam teori bahwa diantara karakteristik kelas unggulan yaitu Kurikulum yang diperkaya, dengan melakukan pengembangan dan improvisasi kurikulum secara maksimal sesuai kebutuhan dan tuntutan belajar. ${ }^{21}$

Sedangkan untuk sarana prasarana program kelas unggulan di MTsN 1 Kabupaten Madiun yaitu disediakan oleh Madrasah dan swadaya wali murid setelah hal tersebut dimusyawarahkan. Hal tersebut diperlukan untuk menunjang pelaksanaan Program Kelas Unggulan dan dapat mencapai tujuan yang telah direncanakan. Hal ini sebagaimana yang disebutkan oleh Suhartono dan Ngadirun dalam teori bahwa diantara karakteristik kelas unggulan yaitu Sarana dan prasarana menunjang untuk pemenuhan kebutuhan pembelajaran dan penyaluran minat dan bakat peserta didik. ${ }^{22}$

Sedangkan terkait dengan pembiayaan, pembiayaan program kelas unggulan di MTsN 1 Kabupaten Madiun berasal dari Dana Operasional Madrasah dan dari jariyah wali murid sebesar Rp. 50.000. pembiayaan tersebut digunakan untuk pemenuhan kebutuhan program kelas unggulan diantaranya yaitu sarana- prasarana, operasional instruktur, pengelola, piket wali kelas, dan biaya lainnya. Operasional instruktur, pengelola dan piket wali kelas ini digunakan untuk menunjang kelancaran pelaksanaan jam tambahan pembelajaran untuk kelas unggulan. Hal ini sebagaimana yang disebutkan oleh Suhartono dan Ngadirun dalam teori bahwa diantara karakteristik kelas unggulan adalah Adanya pembelajaran tambahan di luar kurikulum, program pengayaan dan perluasan, pengajaran remedial, pelayanan bimbingan dan konseling yang berkualitas, pembinaan kreativitas, dan disiplin, sistem asrama, serta kegiatan ekstrakurikuler lainnya. ${ }^{23}$

3. Pelaksanaan

Selain perencanaan dan pengorganisasian, hal yang penting dalam manajemen lainnya adalah pelaksanaan. Adapun pelaksanaan program kelas unggulan di MTsN 1 Kabupaten Madiun dilakukan oleh guru dan instruktur yang kompeten di bidangnya dan sesuai dengan tugasnya masing-masing. Adapun tahapan pelaksanaannya yaitu pendahuluan, pelaksanaan dan evaluasi. Hal ini sebagaimana teori Rusman bahwa Pelaksanaan pembelajaran dalam suatu kegiatan belajar mengajar merupakan implementasi dari rencana pelaksanaan pembelajaran. Pelaksanaan pembelajaran meliputi: kegiatan pendahuluan, kegiatan inti dan kegiatan penutup. ${ }^{24}$

Dalam tahap pendahuluan atau sebelum pengajaran, Guru MTsN 1 Kabupaten Madiun menyususn program tahunan, program semester, tujuan pembelajaran, rencana pelaksanaan pembelajaran (RPP) dan menentukan metode yang akan digunakan agar dapat mencapai tujuan yang telah disusun, seperti untuk kelas multimedia menggunakan media kelas online. Hal ini sebagaimana yang disebutkan Kompri dalam teori bahwa Dalam tahap sebelum pengajaran guru harus menyusun: program tahunan, program satuan pelajaran, dan perencanaan program mengajar. ${ }^{25}$

Sedangkan dalam tahap pelaksanaan pengajaran, guru MTsN 1 Kabupaten Madiun melaksanakan pembelajaran di kelas sesuai dengan rencana pelaksanaan pembelajaran (RPP) yang telah disusun sebelumnya. Hal ini sebagaimana yang disebutkan Kompri

${ }^{21}$ Suhartono dan Ngadirun, "Penyelenggaraan Program Kelas Unggulan di Sekolah Dasar", dalam Jurnal Pendidikan, vol. 6, no. 2, 2005, 114-115.

${ }^{22}$ Ibid.

${ }^{23}$ Ibid.

${ }^{24}$ Rusman, Model-model Pembelajaran, 10.

${ }^{25}$ Kompri, Manajemen Pendidikan (Komponen-Komponen Elementer Sekolah), 102-103. 
dalam teori bahwa Dalam tahap pengajaran ini berlangsung interaksi antara guru dan siswa, siswa dengan siswa, dan siswa grup atau siswa secara individual. ${ }^{26}$

Sedangkan tahap terakhir adalah guru MTsN 1 Kabupaten Madiun melaksanakan evaluasi pembelajaran. Hal ini sebagaimana yang disebutkan Kompri dalam teori bahwa Beberapa kegiatan yang tampak pada tahap sesudah mengajar, antara lain: 1) Menilai pekerjaan siswa, 2) Membuat perencanaan untuk pertemuan berikutnya, 3) Menilai kembali proses belajar mengajar yang telah berlangsung. ${ }^{27}$

Sedangkan jadwal pelaksanaannya yaitu setiap hari senin-sabtu jam 14.30-16.oo. setelah pembelajaran materi kurikulum nasional. Pembelajarannya disesuaikan dengan materi masing-masing program kelas unggulan yang telah disusun sebelumnya. Selain itu juga ada program khusus untuk kelas tahfidz yaitu program tadarus keliling atau khataman keliling. Hal ini sebagaimana teori Kompri bahwa salah satu ciri kelas unggulan adalah Memiliki kurikulum yang diperkaya (eskalasi). ${ }^{28}$ Juga teori dari Suhartono dan Ngadirun yang menyebutkan bahwa diantara karakteristik kelas unggulan adalah Kurikulum yang diperkaya, yakni melakukan pengembangan dan improvisasi kurikulum secara maksimal sesuai dengan kebutuhan dan tuntutan belajar dan adanya perlakuan tambahan di luar kurikulum, program pengayaan dan perluasan, pengajaran remedial, pelayanan bimbingan dan konseling yang berkualitas, pembinaan kreativitas, dan disiplin, sistem asrama, serta kegiatan ekstrakurikuler lainnya. ${ }^{29}$

4. Evaluasi

Tahap terakhir dalam manajemen program kelas unggulan adalah evaluasi. Evaluasi ini dilakukan untuk melihat ketercapaian tujuan yang telah disusun hal ini sebagaimana yang disebutan Ngalim Purwanto bahwa Evaluasi merupakan suatu proses kegiatan yang sistematis untuk menentukan dan membuat keputusan sampai sejauhmana tujuan-tujuan pengajaran telah dicapai oleh peserta didik. ${ }^{30}$ Adapun evaluasi yang dilaksanakan oleh MTsN 1 Kabupaten Madiun adalah evaluasi terprogram yaitu penilaian tengah semester dan evaluasi tidak terprogram yaitu evaluasi yang dilaksanakan masing-masing koordinator program kelas unggulan. Melihat jenis evaluasi yang dilaksanakan MTsN 1 Kabupaten Madiun, evaluasi yang dilaksanakan merupakan evaluasi formatif dan sumatif, evaluasi model Brinkerhoff. Evaluasi formatif yaitu evaluasi tidak terprogram yang dilaksanakan saat pembelajaran berlangsung, yaitu bagian dari tahap setelah pengajaran dalam rencana pelaksanaan pembelajaran dan evaluasi sumatif yaitu evaluasi terprogram yang dilakukan di akhir semester yang bertujuan untuk menilai ketercapaan tujuan pembelajaran program kelas unggulan. Hal ini sebagaimana yang disebutkan S. Eko Putro Widoyoko dalam teori bahwa Brinkerhoff mengemukakan tiga golongan evaluasi yang disusun berdasarkan penggabungan komponen-komponen yang sama, sebagai berikut: a) Fixed vs Emergent Evaluation Design. Desain evaluasi yang tetap (fixed) ditentukan dan direncanakan secara sistemik sebelum implementasi dikerjakan. b) Formative vs Sumative Evaluation. Evaluasi formatif digunakan untuk memperoleh informasi yang dapat membantu untuk memperbaiki program. Evaluasi formatif dilaksanakan pada saat implementasi program sedang berjalan. Sedangkan evaluasi sumatif dilaksanakan untuk menilai manfaat dari suatu program sehingga dari hasil evaluasi tersebut akan dapat menentukan suatu program tertentu akan diteruskan atau dihentikan. c) Experimental and Quasi Experimental Design vs Natural/Unotrusive. Dalam evaluasi ini subjek

\footnotetext{
${ }^{26}$ Ibid.

${ }^{27}$ Ibid.

${ }^{28}$ Kompri, Manajemen Pendidikan (Komponen-Komponen Elementer Sekolah), 90-91.

${ }^{29}$ Ibid.

${ }^{30}$ Ngalim Purwanto, Prinsip-Prinsip Evaluasi Pengajaran (Bandung: Rosda Karya, 2002), 75.
} 
penelitian diacak, perlakuan diberikan dan pengukuran dampak dilakukan. Tujuan dari evaluasi ini untuk menilai manfaat suatu program yang dicobakan. ${ }^{31}$

Selain dari hal diatas untuk mengetahui ketercapaian suatu tujuan program pembelajaran juga dapat dilihat dari prestasi masing-masing program kelas unggulan. Adapun ditahun 2019 MTsN 1 Kabupaten Madiun memperoleh prestasi di masing-masing program kelas unggulan yaitu prestasi kelas excellent antara lain Juara harapan 2 Olimpiade Matematika di MAN 2 Ponorogo, Juara harapan 2 Olimpiade Matematika dan Sains di SMA 1 Babadan Ponorogo, Juara 2 Olimpiade Fisika di SMA Muhammadiyah 1 Ponorogo, juara 1 English Speech Contest di MAN 1 Madiun, Juara 1 IPS Terintegrasi, dan Juara 3 Matematika Terintegrasi. Prestasi kelas tahfidz antara lain Juara 1 MTQ MAN 2 Ponorogo, Juara 3 MTQ Pondok Tarbiyatul Mutatowwirin, Juara 1 MTQ SMA 1 Babadan Ponorogo, Juara 2 MSQ MAN 1 Madiun, dan Juara 2 Tahfidz Putra Porseni se-Kabupaten Madiun. Prestasi Kelas Multimedia adalah Juara Harapan 2 Vlog Kemenag Madiun. Prestasi Kelas Olahraga dan Seni antara lain Juara 2 Futsal MAN 3 Madiun, Juara 3 Futsal SMK Ar-Rahman, Juara 1 Lari 100 m Putri Porseni Se-Kabupaten Madiun, Juara 1 Lari 400 m Putri Porseni Se-Kabupaten Madiun, Juara 1 Lompat Jauh Putra dan Putri Porseni Se-Kabupaten Madiun, Juara 1 Tolak Peluru, Juara 1 Bulu Tangkis Tunggal Putri, Juara 1 Tenis Meja Tunggal Putra, Tenis Meja Ganda Putra, Juara 1 Catur Putra, Juara 2 Futsal, dan Juara 2 Voley Porseni Se-Kabupaten Madiun. Hal ini sebagaimana yang disebutkan Zainul dan Nasution dalam Ngalim Purwanto dalam teori bahwa bahwa evaluasi dapat dinyatakan sebagai suatu proses pengambilan keputusan dengan menggunakan informasi yang diperoleh melalui pengukuran hasil belajar, baik yang menggunakan instrumen tes maupun non tes. ${ }^{32}$

Dari analisis diatas dapat dipahami bahwa manajemen program kelas unggulan untuk meningkatkan citra madrasah di MTsN 1 Kabupaten Madiun menerapkan 4 fungsi manajemen yaitu perencanaan, pengorganisasian, pelaksanaan dan evaluasi. Adapun lebih jelasnya dapat dilihat pada tabel dibawah ini:

\begin{tabular}{|c|c|c|c|}
\hline \multicolumn{4}{|c|}{$\begin{array}{c}\text { Manajemen Program Kelas Unggulan untuk Meningkatkan Citra } \\
\text { Madrasah }\end{array}$} \\
\hline $\begin{array}{l}\text { Perencanaan } \\
\text { - Tujuan } \\
\text { - Program } \\
\text { - Anggaran }\end{array}$ & $\begin{array}{l}\text { Pengorganisasian } \\
\text { - Struktur organisasi } \\
\text { - Pendidik } \\
\text { - Peserta didik } \\
\text { - Materi } \\
\text { - Sarana prasarana } \\
\text { - Biaya }\end{array}$ & $\begin{array}{l}\text { Pelaksanaan } \\
\text { - Sebelum } \\
\text { pengajaran } \\
\text { - Pengajaran } \\
\text { - Setelah pengajaran }\end{array}$ & $\begin{array}{l}\text { Evaluasi } \\
\text { - Formatif } \\
\text { - Sumatif } \\
\text { - Test } \\
\text { - Non test }\end{array}$ \\
\hline
\end{tabular}

\section{Kendala dalam Manajemen Program Kelas Unggulan untuk Meningkatkan Citra Madrasah Di MTsN 1 Kabupaten Madiun}

Dalam pelaksanaan program kelas unggulan di MTsN 1 Kabupaten Madiun juga mengalami kendala atau hambatan baik dari dalam madrasah maupun dari luar madrasah. Hal

\footnotetext{
${ }^{31}$ S. Eko Putro Widoyoko, Evaluasi Program Pembelajaran (Yogyakarta: Pustaka Pelajar, 2012), 173189.

${ }^{32}$ Ngalim Purwanto, Prinsip-Prinsip Evaluasi Pengajaran, 75.
} 
ini sebagaimana yang disebutkan oleh Dimyati dan Sudjiono dalam teori bahwa problematikapembelajaran berasal dari dua faktor yaitu faktor intern dan ekstern. ${ }^{33}$ Adapun kendala dalam perencanaan program kelas unggulan dalam meningkatkan citra di MTsN 1 Kabupaten Madiun adalah terbatasnya anggaran dan setiap akan mengadakan event harus melalui persetujuan walimurid karena masih bergantung kepada Iuran dari orang tua siswa.

Kendala dalam pengorganisasian program kelas unggulan dalam meningkatkan citra di MTsN 1 Kabupaten Madiun yaitu belum terwujudnya kurikulum khusus untuk masing-masing program kelas unggulan, pengalokasian jam pembelajaran khusus untuk kelas unggulan, dan minimnya tenaga pendidik profesional yang sesuai dengan program kelas unggulan yang diselenggarakan di MTsN 1 Kabupaten Madiun. Misal tenaga pendidik bimbingan Olimpiade dan KIR.

Kendala yang dihadapi dalam pelaksanaan program kelas unggulan di MTsN 1 Kabupaten Madiun antara lain: Adanya pasang-surut, Kres dengan kepentingan-kepentingan lain, Sarana yang tidak cepat terpenuhi, Waktu Kegiatan bimbingan yang terbatas, Sering kali siswa juga mengikuti kegiatan Ekstrakurikuler, sehingga sering jadwal kegiatan berbenturan, Musim Ujian, Musim Hujan, siswa tidak sebanding dengan jumlah guru, dan bapak ibu guru yang belum maksimal menerapkan pembelajaran berbasis IT.

Sedangkan kendala dalam evaluasi manajemen program kelas unggulan di MTsN 1 Kabupaten Madiun adalah adanya perubahan rapor dari manual ke ARD, tidak semua guru melek IT dan terbatasnya sarana komputer untuk pelaksanaan evaluasi. Adapun lebih jelasnya dapat dilihat pada bagan dibawah ini:

\section{Kendala Manajemen Program Kelas Unggulan untuk Meningkatkan Citra Madrasah}

\section{Perencanaan}

- Terbatasnya anggaran

- Setiap akan mengadakan event harus melalui persetujuan walimurid karena masih bergantung kepada Iuran dari orang tua siswa.

\section{Pengorganisasian}

- Belum terwujudnya kurikulum khusus untuk masing-masing program kelas unggulan

- Pengalokasian jam pembelajaran khusus untuk kelas unggulan

- Minimnya tenaga pendidik profesional yang sesuai dengan program kelas unggulan

\section{Pelaksanaan}

- Adanya pasang-surut

- Kres dengan kepentingan-kepentingan lain

- Sarana yang tidak cepat terpenuhi

- Waktu Kegiatan bimbingan yang terbatas

- Jadwal kegiatan berbenturan

- Musim Ujian

- Musim Hujan

- Siswa tidak sebanding dengan jumlah guru

- Bapak dan Ibu guru yang belum maksimal menerapkan pembelajaran berbasis IT.

\section{Evaluasi}

- Adanya perubahan rapor dari manual ke ARD

- Tidak semua guru melek IT

Terbatasnya sarana komputer untuk pelaksanaan evaluasi.

\footnotetext{
${ }^{33}$ Dimyati dan Mudjiono, Belajar dan Pembelajaran, (Jakarta: Rineka Cipta, 2010), 235-254.
} 


\section{Implikasi Manajemen Program Kelas Unggulan terhadap Peningkatan Citra Madrasah Di MTsN 1 Kabupaten Madiun}

Program kelas unggulan dengan manajemen yang bagus akan menjadi salah satu cara untuk meningkatkan citra madrasah. Sedangkan citra yang ingin dibangun melalui manajemen program kelas unggulan ini adalah siswa yang mengikuti program kelas prestasi dapat berprestasi dalam bidang akademik, hafal juz 30, menguasai 2 bahasa yaitu bahasa inggris dan bahasa arab. Siswa yang mengikuti kelas tahfidz dapat menghafalkan al-qur'an sebanyak 7 juz, mahir dalam dakwah. Siswa yang mengikuti kelas multimeda/IT dapat mengoperasikan aplikasi perkantoran, desain grafis, video editing dan hafal juz 3o. Sedangkan siswa yang mengikuti program kelas Olahraga dan seni dapat memiliki kemampuan dibidang athletik, permainan, aksioma dan seni, serta hafal juz 30.

Dalam meningkatkan citra MTsN 1 Kabupaten Madiun ada beberapa hal yang menjadi faktor pembentuk citra diantaranya yaitu: 1) Identitas Fisik, 2) Identitas Nonfisik, 3) Kualitas Hasil, Mutu, dan Pelayanan dan 4) Aktivitas dan Pola Hubungan. ${ }^{34}$ Adapun manajemen program kelas unggulan termasuk ke dalam faktor kualitas hasil, mutu dan pelayanan dan aktifitas dan pola hubungan.

1. Kualitas hasil, mutu dan pelayanan

Kualitas hasil Program kelas unggulan dapat dilihat dari output yang dihasilkan dan prestasi yang diraih. Sedangkan kualitas mutu dan pelayanan dapat terlihat dari manajemen program kelas unggulan yang telah dibahas sebelumnya. Hal ini sebagaimana yang disebutkan oleh Syariffudin S. Gassing dan Suryanto dalam teori bahwa Citra sebuah sekolah/madrasah juga terbentuk dari hasil dan mutu sebuah produk. Sebuah produk yang dirancang, baik barang atau jasa, mencerminkan kualitas manajemennya. Semakin baik hasil sebuah kinerja dengan dibarengi mutu yang tetap dijaga, bukan tidak mungkin citra sekolah/madrasah akan semakin baik dimata masyarakat. Untuk menunjang dan menjaga mutu yang telah dihasilkan perlu adanya pelayanan yang memuaskan terhadap masyarakat. Dalam konteks ini adalah pelayanan yang maksimal dan prima berupa jasa kepada peserta didik dan orang tua siswa. ${ }^{35}$

2. Aktifitas dan pola hubungan

Aktifitas dan pola hubungan ini dapat tercermin dalam melibatkan wali murid dalam perencanaan program kelas unggulan, baik terkait sarana prasarana maupun anggaran. Selain itu juga perkembangan peserta didik yang selalu dilaporkan kepada wali murid. Sedangkan untuk menjaga hubungan dengan pihak eksternal diadakan tadarus dan khataman keliling di masjid atau mushola sekitar. Hal ini sebagaimana yang disebutkan oleh Syariffudin S. Gassing dan Suryanto dalamteori bahwa Jika sebuah sekolah/madrasah sudah mempunyai produk jasa dengan mutu yang terjaga, maka menjaga hubungan dengan pemangku pendidikan harus selalu kontinue. Aktivitas dan pola hubungan dengan stakeholder internal maupun eksternal mencerminkan citra sekolah/madrasah. Memberikan respon yang jujur, kepercayaan dan memperlihatkan tanggung jawab adalah suatu hal yang harus dilaksanakan. ${ }^{36}$

Dari analisis diatas dapat diketahui faktor pembentuk citra dalam program kelas unggulan di MTsN 1 Kabupaten Madiun. Apabila di gambarkan sebagaimana tabel dibawah ini:

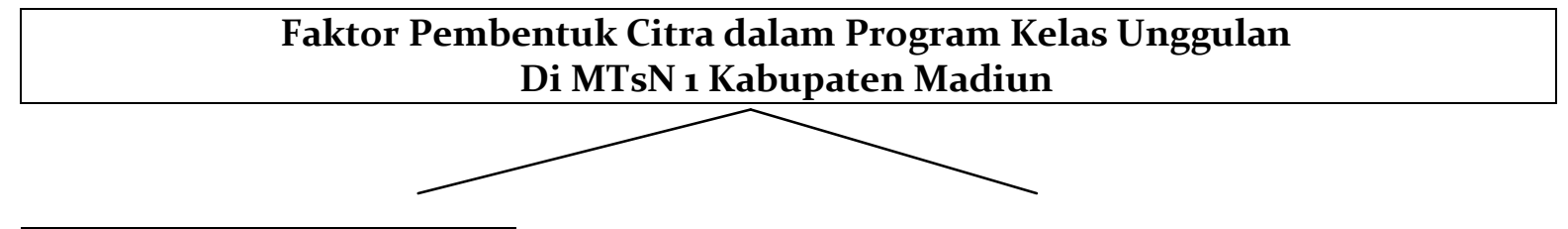

\footnotetext{
${ }^{34}$ Syariffudin S. Gassing dan Suryanto, Public Relation (Yogyakarta: Andi, 2016), 159-160.

${ }^{35}$ Ibid.

${ }^{36} \mathrm{Ibid}$.
} 


\begin{tabular}{|ll|}
\hline Kualitas hasil, mutu dan \\
pelayanan \\
- & Output \\
- & Prestasi \\
\hline & Kualitas layanan/ manajemen \\
\hline
\end{tabular}

\begin{tabular}{|ll|}
\hline \multicolumn{2}{|l|}{ Aktivitas dan Pola Hubungan } \\
- & Melibatkan wali murid dalam perencanaan \\
& sarana dan prasarana dan anggaran \\
- & Pelaporan anggaran \\
- & Pelaporan perkembangan siswa \\
- & Tadarus dan khataman keliling \\
\hline
\end{tabular}

Sedangkan alasan konsumen yang dalam hal ini adalah siswa dan wali murid memilih MTsN 1 Kabupaten Madiun bermacam-macam yaitu terdapat program kelas unggulan, terdapat banyak kegiatan ekstrakurikuler, adanya dorongan dari pihak luar, memiliki kualitas yang baik, memiliki banyak prestasi, memiliki keunggulan dibidang IPTEK dan IMTAQ, jarak dari rumah dekat, merupakan sekolah yang bagus, maju dan favorit serta banyak alumninya yang di terima di sekolah favorit. Sedangkan, pendapat mereka tentang program kelas unggulan di MTsN 1 Kabupaten Madiun beragam, yaitu: dapat menumbuhkan semangat belajar dan ingin masuk kelas unggulan, dapat menambah ilmu dan mengembangkan kemampuan siswa, sebagai sarana penjaringan siswa yang berprestasi, dapat sebagai sarana siswa untuk menyalurkan bakat dan dapat menambah peminat yang ingin bersekolah di MTsN 1 Kabupaten Madiun. Hal ini sebagaimana yang disebutkan oleh Elvinaro Adrianto dalam teori bahwa Terdapat empat peran citra bagi suatu lembaga, yaitu: Citra mempunyai dampak pada adanya pengharapan, Citra adalah sebagai penyaring yang memengaruhi persepsi pada kegiatan lembaga, Citra adalah fungsi dari pengalaman dan juga harapan konsumen, dan Citra mempunyai pengaruh penting pada manajemen. ${ }^{37}$

Dari analisis diatas dapat diketahui citra apa yang ingin dibangun dan implikasi dari manajemen program kelas unggulan di MTsN 1 Kabupaten Madiun terhadap citra madrasah. Apabila digambarkana seperti tabel dibawah ini:

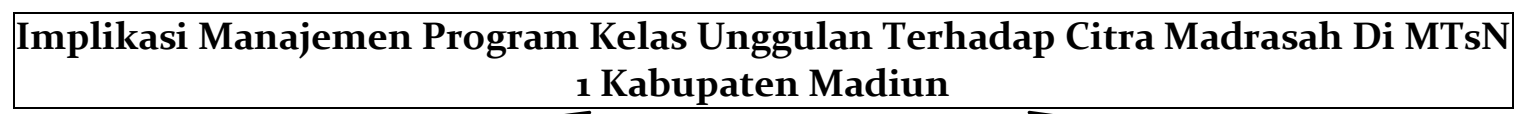

\section{Citra yang Ingin Dibangun}

Program Kelas Prestasi:

Dapat berprestasi dalam bidang akademik

Hafal juz 30

- Menguasai 2 bahasa yaitu bahasa inggris dan bahasa arab

Program Kelas Tahfidz:

- Dapat menghafalkan al-qur'an sebanyak 7 juz

- Mahir dalam dakwah

Program Kelas Multimeda/IT:

- Dapat mengoperasikan aplikasi perkantoran

- Desain grafis

- Video editing

- Hafal juz 30

Program kelas Olahraga dan seni:

- Dapat memiliki kemampuan dibidang athletik, permainan, aksioma dan seni

- Hafal juz 30

\begin{tabular}{|lll|}
\hline \multicolumn{3}{|c|}{ Citra yang Diperoleh } \\
- & Memiliki kualitas \\
& yang baik \\
- & Memiliki banyak \\
& prestasi \\
- & Memiliki \\
& keunggulan dibidang \\
& IPTEK dan IMTAQ \\
- & Merupakan sekolah \\
yang bagus, maju \\
dan favorit \\
Memiliki sarana \\
untuk \\
mengembangkan \\
kemampuan, bakat \\
dan minat siswa \\
\end{tabular}

\footnotetext{
${ }^{37}$ Elvinaro Adrianto, Public Relation Praktis (Bandung: Widya Padjajaran, 2009), 22.
} 


\section{Kesimpulan}

Dari hasil penelitian diatas, peneliti akan memberikan kesimpulan terkait manajemen program kelas unggulan untuk meningkatkan citra madrasah di MTsN 1 Kabupaten Madiun.

1. Manajemen program kelas unggulan untuk meningkatkan citra madrasah di MTsN 1 Kabupaten Madiun menerapkan 4 fungsi manajemen yaitu perencanaan, pengorganisasian, pelaksanaan dan evaluasi. Perencanaan, hal-hal yang dirumuskan dalam perencanaan meliputi: tujuan, program, dan anggaran. Pengorganisasian meliputi hal-hal yang dirumuskan dalam pengorganisasian, yaitu struktur organisasi, pendidik, peserta didik, materi, sarana prasarana, biaya. Pelaksanaan meliputi langkah-langkah yang dilakukan dalam pelaksanaan, yaitu: Sebelum pengajaran, Pengajaran dan Setelah pengajaran. Selanjutnya evaluasi dilakukan dengan cara Formatif, Sumatif, Test dan Non test.

2. Kendala dalam manajemen program kelas unggulan untuk meningkatkan citra di MTsN 1 Kabupaten Madiun ada dalam setiap fungsi manajemen. Kendala dalam perencanaan: Terbatasnya anggaran, Setiap akan mengadakan event harus melalui persetujuan walimurid karena masih bergantung kepada Iuran dari orang tua siswa. Kendala dalam pengorganisasian: Belum terwujudnya kurikulum khusus untuk masing-masing program kelas unggulan, Pengalokasian jam pembelajaran khusus untuk kelas unggulan, Minimnya tenaga pendidik profesional yang sesuai dengan program kelas unggulan. Kendala dalam pelaksanaan: Adanya pasang-surut, Kres dengan kepentingan-kepentingan lain, Sarana yang tidak cepat terpenuhi, Waktu Kegiatan bimbingan yang terbatas, Jadwal kegiatan berbenturan, Musim Ujian, Musim Hujan, Siswa tidak sebanding dengan jumlah guru dan Bapak dan Ibu guru yang belum maksimal menerapkan pembelajaran berbasis IT. Kendala dalam evaluasi: Adanya perubahan rapor dari manual ke ARD, Tidak semua guru melek IT dan Terbatasnya sarana komputer untuk pelaksanaan evaluasi.

3. Implikasi Manajemen Program Kelas Unggulan terhadap Citra Madrasah Di MTsN 1 Kabupaten Madiun diantaranya yaitu: Memiliki kualitas yang baik, Memiliki banyak prestasi, Memiliki keunggulan dibidang IPTEK dan IMTAQ, Merupakan sekolah yang bagus, maju dan favorit dan Memiliki sarana untuk mengembangkan kemampuan, bakat dan minat siswa.

\section{Daftar Pustaka}

Adam, Muhammad. Manajemen Pemasaran Jasa. Bandung: Alfabeta, 2015.

Adrianto, Elvinaro. Public Relations suatu Pendekatan Praktis. Bandung: Pustaka Bani Quraisy, 2004 .

Alika, Rizky. "Nadiem: Anak Indonesia Krisis Percaya Diri, Butuh Manajemen Talenta". 23 Desember 2019, https://katadata.co.id/berita/2019/12/23/nadiem-anak-indonesiakrisis-percaya-diri-butuh-manajemen-talenta, diakses tanggal 26 Januari 2020

Alma, Buchari.Manajemen Pemasaran dan Pemasaran Jasa. Bandung: Alfabeta, 2007.

Dimyati dan Mudjiono. Belajar dan Pembelajaran. Jakarta: Rineka Cipta, 2010.

Fattah, Nanang. Landasan Manajemen Pendidikan. Bandung: Remaja Rosdakarya, 2009.

Gassing, Syariffudin S. dan Suryanto. Public Relation. Yogyakarta: Andi, 2016. 
Kompri. Manajemen Pendidikan (Komponen-Komponen Elementer Sekolah). Yogyakarta: ArRuzz Media, 2015.

Kurniadin, Didin dan Machali, Imam. Manajemen Pendidikan: Konsep dan Prinsip Pengelolaan Pendidikan. Yogyakarta: Ar-Ruzz Media, 2012.

Purwanto, Ngalim. Prinsip-Prinsip Evaluasi Pengajaran. Bandung: Rosda Karya, 2002.

Rusman. Model-model Pembelajaran. Jakarta: PT Rajagrafindo Persada, 2013.

Suhartono dan Ngadirun. "Penyelenggaraan Program Kelas Unggulan di Sekolah Dasar". Jurnal Pendidikan, vol. 6, no. 2, 2005, .

Sukmadinata, Nana Syaodih, et.al.. Pengendalian Mutu Pendidikan Sekolah Menengah. Bandung: Refika Aditama, 2006.

Suryadi. Manajemen Mutu Berbasis Sekolah. Bandung: PT Sarana Panca Karya Nusa, 2009.

Widoyoko, S. Eko Putro. Evaluasi Program Pembelajaran. Yogyakarta: Pustaka Pelajar, 2012 